\title{
Urban Governance and Civic Responsibility: Interwar Council Housing in Buxton
}

\author{
T J HULME \\ University of Leicester
}

Councillors and locals alike in Buxton, Derbyshire, had a strong sense of civic identity relating to the town's reputation as a spa and site of leisure in the interwar period. The council clearly saw its civic role as maintaining this prestigious image. The imposition of housing powers from the central government in 1919 therefore raised an important question in the area: how far did the council's responsibility to housing the local working classes extend now that they had the means to improve conditions? The unpredictable complexities of state policy certainly had an effect on the progress of housing schemes in the town, yet a close examination of the intricate and local culture of perceived responsibility reveals the importance of a very localised decision-making process. From the resolution to build, through the problems in implementing housing schemes, to the management of tenants and property following construction, it was the local authority that had the power to make substantial changes. Buxton was a small rural town, without a popular belief that it was blighted by typical urban problems of overcrowding and slums. It instead looked to its status as a spa town to inform housing policy decisions. By elucidating Buxton's experience, as opposed to larger industrial cities with familiar problems of housing and slums, a different analysis of local intervention can be contributed to the historiography of council housing in Britain.

KEYWORDS Buxton, civic identity, council housing, interwar housing, spa

With the introduction of the Housing, Town Planning \&c Act I9I9, a defining moment in the development and extent of British state intervention was reached. ${ }^{\mathrm{I}}$

\footnotetext{
My special thanks to Professor Simon Gunn of the University of Leicester and Dr Nick Hayes of Nottingham Trent University for their invaluable guidance, criticisms and suggestions in researching and writing this piece.
} 
This act, which included an exchequer subsidy for municipal house building, was the first of many housing measures passed in the interwar period, as definitions of state responsibility for housing changed and adapted to the political and economic forces working within Britain. Whilst the state was the facilitator of housing subsidies, it was local authorities that were required to investigate housing need in the area, plan housing schemes under ministry of health supervision, build the houses, and fulfil the role of landlord. Buxton in this period was a small rural town that still proudly held onto its eighteenth- and nineteenth-century heritage as a luxurious spa location. By assessing the development and idiosyncratic results of housing policy in this place, as opposed to the larger and more urban industrial centres with outwardly recognisable housing issues, a contribution can be made to the history of local politics and decision-making in the interwar period.

The origin of state intervention has been well documented in the historiography of housing. After the introduction of the Land Value Duties in I9Io the output of houses, which had already been falling, decreased markedly, to the extent that losses to the housing stock through demolition were not balanced with construction in some towns. ${ }^{2}$ The demanding nature of total war meant that the building of houses had come to a virtual standstill between I9I4 and I9I8, as labour and materials flowed to war work. ${ }^{3}$ At the end of the First World War, therefore, housing requirements stood at approximately 600,000. ${ }^{4}$ The fundamental issue in the development of housing policy at the central level was the realisation that private enterprise, under the imposition of the Rent and Mortgage Interest (War Restrictions) Act, could not meet this deficit and provide houses to be let at a profitable rent. The principle of a subsidy to offset these restrictive conditions was first formally discussed in I9I6, and was generally accepted within the government as a finite, but necessary, measure to overcome the housing shortage. ${ }^{5}$

Rising industrial and social disturbances formed the backdrop to the introduction of this subsidy, with over thirty-five million days lost in strikes in I9I9, compared to five million in I918. ${ }^{6}$ The strength of the labour movement had increased during the war years, as the membership of trade unions grew from four million in I9I 3 to eight million in 1919. ${ }^{7}$ Whilst there has been some disagreement with regard to the extent this rising industrial strength and unrest had on informing the government's decision, the 'homes fit for heroes' campaign, as championed by Lloyd George, certainly promised to radically improve the conditions of housing. Whether or not this was out of a genuine concern for social conditions of housing, or as a way to placate potential revolutionaries, is certainly debatable. ${ }^{8}$ Yet local authorities had been given new

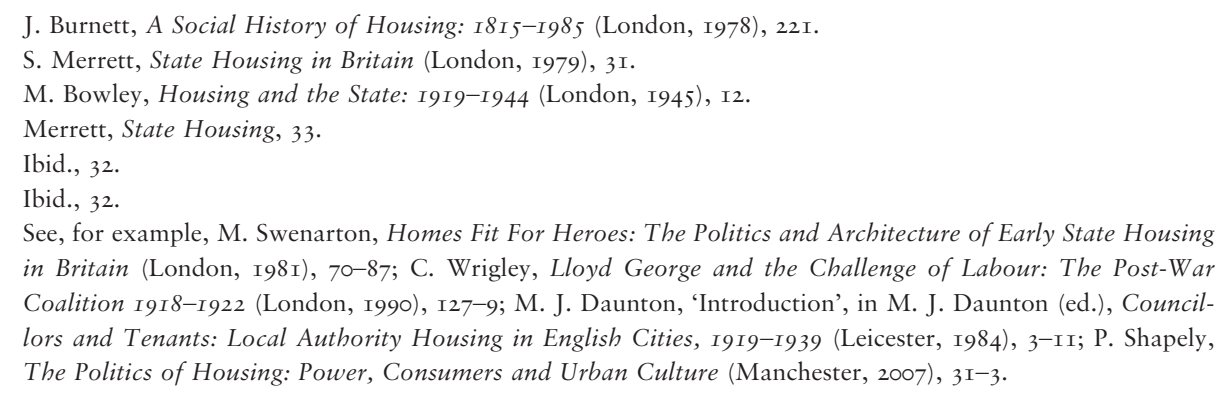


and daunting powers that could greatly change and improve local conditions. Some, however, were much more reluctant than others. ${ }^{9}$ The question centred then on whether individual local councils would choose, and continue to choose, to exercise that authority, and if so, under what conditions and constraints.

Whilst Buxton was relatively small with a population of approximately 15,600 in I92I, there was some recognition that there was a housing problem in the area. ${ }^{\text {IO }}$ Although the initial deficit was judged to be small and manageable, at only one hundred houses, the council still struggled to build (see Table I). ${ }^{\text {II }}$ The result of this was an increasing deficit. As the population grew to $18,800,{ }^{\mathrm{I} 2}$ and over I 30 houses were condemned by the health committee, ${ }^{\mathrm{I} 3}$ private enterprise still failed to alleviate the problem of a lack of affordable housing stock. This deficit was not cleared at any stage; the council did not build any houses after I933 and, in I939, the situation had deteriorated far beyond the i9r9 level.

Whilst state legislation and central-local relations also affected Buxton's housing policy, it is the notions of civic responsibility, and the perception of the local authorities and local press, that can explain so vividly the response of the Buxton council. This will hopefully reaffirm that the history of council housing does not end with the formulation of policy at the central level, ${ }^{\mathrm{I}}$ since the decision-making process

TABLE 1

HOUSES BUILT IN BUXTON IN THE INTERWAR PERIOD

\begin{tabular}{lc}
\hline Year building commenced & Houses built \\
\hline 1921 & 3 \\
1923 & 26 \\
1924 & 36 \\
1926 & 68 \\
1930 & 40 \\
1931 & 40 \\
1933 & 60 \\
Total & 273 \\
\hline
\end{tabular}

SOURCE: DRO, 'HATPCM’ (1918-1945).

9 Jennings has shown the large disparities in building rates between local authorities. For example, under the Wheatley Act of I924, at opposing ends of the scale, Carlisle built 45.5 per Iooo people, Walsall 40.8 , and Smethwick 33.9, whilst Salford, Grimsby, Blackpool, Croydon and Southend all failed to build more than I.3 houses per Iо00: J. H. Jennings, 'Geographical Implications of the Municipal Housing Programme in England and Wales I919-I939', Urban Studies, 8/2 (June I97I), I28.

Io 'Population, Acreage, Private Families and Dwellings', I92I Census of England and Wales, Derbyshire County Report, Table 3, viewed at http://www.visionofbritain.org.uk.

II Derbyshire Record Office (hereafter DRO), 'Housing and Town Planning Committee Minutes' (hereafter 'HATPCM'), Di323/2/I8/I (io February I919).

I2 'Population by Sex and Year of Birth (and Age) in Great Britain and the Isle of Man. England and Wales Counties, Boroughs, Urban and Rural Districts', 1939 National Registration of United Kingdom and Isle of Man, Population summary, Table 3A, viewed at http://www.visionofbritain.org.uk.

${ }^{13}$ DRO, 'Health Committee Minutes' (hereafter 'HCM'), DI323/2/I 5/2-4 (I930-I939).

I4 Daunton, 'Introduction', Councillors and Tenants, 3. 
at the local level was both complex and changeable; consequently, so were the results. By analysing the unique notions of civic responsibility that operated in Buxton, the local decision-making process can be fully explained. Councillors, the press and locals alike had a convoluted view of who held responsibility for housing, and this clearly affected the formation of policy at the local level.

\section{The nature of civic responsibility}

Existing studies of local interwar housing schemes have concentrated on the political composition of the authorities in question, with most studies showing that a Labour council was more likely to implement a progressive policy with regards to housing, when compared relatively with a Conservative dominated council. ${ }^{15}$ Yet more recent work has emphasised the need to assess municipal action within a framework of civic culture and notions of civic responsibility. Hayes particularly has highlighted the importance of 'a city's intrinsic view of itself' in the decision-making process; political allegiance mattered less than an authority's perception of need and responsibility. ${ }^{\text {I6 }}$

Members of the Buxton council stressed, at least to the local populace, the value of refraining from party politics altogether. At one point Councillor Howe stated that he 'never wished to bring political issues into local government', a stance the local press supported throughout the period. ${ }^{17}$ Indeed, the opposition towards political allegiance from the press can be seen in the occasion any candidate stood for a party. For example, the Herald recognised in 1923 the Labour Party's 'grave error of judgement and tactical blunder' in nominating a candidate to challenge the highly popular non-party Councillor Goodwin, and was proved right with the subsequent landslide defeat. ${ }^{18}$ Surviving records of clear political allegiance are lacking, perhaps due to the absence of the importance applied to such allegiances, or the implications of publicly campaigning on a party political basis. ${ }^{19}$ The composition of the council at the outbreak of war in I939 however displays a telling picture: of twenty-two councillors, fourteen claimed to be Independent, five were Labour, and three were Ratepayers Association members. ${ }^{20}$

Although the rate of house building was slow, this is not to suggest that every member of the council disagreed with a policy of intervention. Still, it was only a minority that whole-heartedly supported the council as a provider of houses - especially at the start of the period. Unsurprisingly perhaps, as an employer of a large amount of labour in Buxton and also the chairman of the industrial council of Buxton, Councillor Ryan radically advocated the construction of some I 300 houses

I5 R. Ryder, 'Council House Building in County Durham, I900-r939: The Local Implementation of National Policy', in Daunton, Councillors and Tenants, 39-100, at 50.

${ }^{16}$ N. Hayes, 'Civic Perceptions: Housing and Local Decision-Making in English Cities in the I92os', Urban History, 27/2 (2000), 2II. See also Shapely, Politics of Housing, which focuses on Manchester.

17 Buxton Herald (hereafter BH), 'Behind the Civic Chair' (hereafter 'BTCC') (6 October I938).

I8 $B H$, 'Council Minutes' (hereafter 'CM') (25 October I923).

I9 B. Keith-Lucas and P. G. Richards have noted the tendency of candidates in this period to use titles such as Independent, Municipal Reform, Ratepayers, Progressive, Municipal Alliance, and others; hence the difficulty of ascertaining the political loyalties of local politicians: B. Keith-Lucas and P. G. Richards, A History of Local Government in the Twentieth Century (London, I978), I00, III-I2.

$20 \mathrm{BH}$, 'Occasional Notes' (5 November 1936). 
as soon as possible. ${ }^{2 \mathrm{I}}$ The Buxton Herald ridiculed such grand schemes, describing with apparent glee the consequent failure of the 'vision' for a 'sort of workers paradise' on Heath Grove, which became the main site for Buxton council houses. ${ }^{22}$ Several councillors, however, agreed on the necessity of municipal action on more moral grounds. When considering Lloyd George's promise of 'homes fit for heroes' Councillor Hall candidly stated that 'they had got some heroes in Buxton' and argued that the Buxton council should meet such a promise. ${ }^{23}$

These notions of civic responsibility, however, were much more prevalent in the preliminary stages of interventionist discussion than the actual planning of schemes. When Councillor Swain, another supporter of progressive policies in housing, suggested a starting scheme of I 28 houses, the response was unenthusiastic. Councillor Goodwin, the chairman of the Housing Committee, insisted 'Let us start with forty first. ${ }^{24}$ This was characteristic of the interwar period in Buxton; cautiousness was consistently advocated over speculation. Councillor Buckley, seen by the more reformist councillors as consistently 'putting the matter on the shelf', ${ }^{25}$ stressed the need to approach the matter of housing slowly. ${ }^{26}$ This is understandable; the imposition of house building powers so suddenly upon a small council, such as in Buxton, could certainly represent an overwhelming experience. Furthermore, the Buxton council, and to a lesser extent the local press, had a tendency to see overcrowding and slum housing as a particularly urban phenomenon that did not apply in Buxton. Even though the health committee calculated in 1936 that 5.08 per cent of workingclass dwellings in Buxton were overcrowded, compared to a national average of 3.08 per cent, the fact that these properties were dispersed across the town rather than concentrated in districts, as in larger urban areas, seemed to quell any notion of Buxton being a town that was facing a distinctively pressing housing problem. ${ }^{27}$

The argument externally voiced in favour of cautiousness was concerned with the necessity to keep down the rates. As a member of the finance committee for most of the interwar period, with a stint as the local chancellor of the exchequer in the I930s, Councillor Buckley held much sway in the decision-making process. Whilst one must be cautious of attributing causation to an individual, especially when discussing a council consisting of twenty-two members, Buckley strongly did not favour housing policy if it involved municipal subsidy from the rates, and consistently argued for this position. ${ }^{28} \mathrm{He}$ was not alone in this belief; the announcement of any decrease in the rates was met with cries of 'hear hear' and applause. ${ }^{29}$ The Herald was certainly a constant advocate of the importance of this responsibility to the ratepayers of Buxton, questioning whether 'a local authority ought to burden the rates with a charge of this nature'. ${ }^{30}$ Bromley and Hayes have noted the importance of the provincial press in

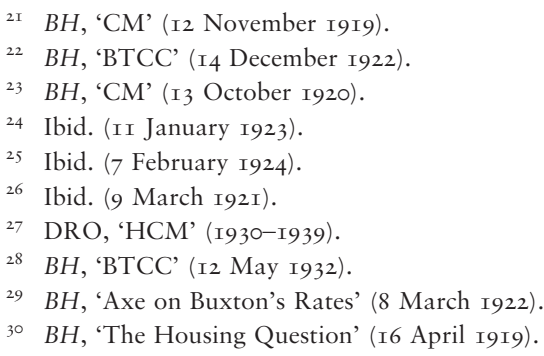


this period, as the 'mediator of civic constructs of progressiveness and improvement'. ${ }^{\text {I }}$ Whilst it is difficult to quantify precisely the impact that the press had on shaping civic culture, it is viable to suggest that the Herald did enhance and justify the persistent arguments emerging from the council chamber.

In Buxton the burden on the rates was approximately 2 per cent of the total income in I932, after the council had built 2I 3 of the eventual 273 houses. ${ }^{32}$ Whilst this desire to decrease the reliance on the rates to a minimum is understandable, it is when a comparison is made with expenditure in other areas that the motivations of the council are revealed. In the same budget the rate deficiency of the Buxton Natural Baths and Wells was II.5 per cent, whilst the maintenance of the Pavilion Gardens was 8 per cent. Such expenditure, essentially subsidising the town's attractions which were actually running at a loss, was deemed necessary for the 'future prosperity of this town' in generating a return income. ${ }^{33}$ It was in the preservation of Buxton's civic identity as a spa and leisure town therefore through investment, rather than spending to provide housing as a social service, that the council saw its prime responsibility.

This did not allow for the fact that a proportion of Buxton's inhabitants were actually members of an industrial working class. As the borough surveyor observed when discussing plans for post-I945 development: 'Buxton is a spa and Buxton is the centre of an important quarrying and lime-burning industry.' 34 Yet the spa function of the town was seemingly diminishing. Whilst there were 'queues outside the picture houses', the Opera House was 'empty', the Pavilion Gardens were 'poorly attended', and the Baths were making a loss of as much as six thousand pounds a year. ${ }^{35}$ These ailing ventures were being subsidised by those who seemingly had no wish to use them. This was a fact not missed by Councillor Bounds and Councillor Bagshaw two of the emerging progressive characters of the council in the I930s. As Bounds stated:

Housing [is] only costing a three penny rate, but what about the Is. 6d. paid by the railwaymen, the quarrymen and other workers, for the Baths? What benefit did they receive? ${ }^{36}$

Prevailing beliefs circulating within the council were that civic responsibility for housing lay outside the remit of local authorities. Most Buxton councillors instead viewed their civic responsibility as investing in enterprises that they believed would generate tourism, and thus income for the town. If there was to be a body that built houses, not out of speculation and enterprise but to provide for the working classes, it should be the local employers of labour - a policy the Herald also supported for the majority of the interwar years. ${ }^{37}$ But it was mainly private industry the council

${ }^{3}$ M. Bromley and N. Hayes, 'Campaigner, Watchdog or Municipal Lackey? Reflections on the Inter-War Provincial Press, Local Identity and Civic Welfarism', Media History, 8/2 (2002), I97.

32 Based on calculations from BH, 'Buxton's Budget' (Io March I932). Whilst this does seem very low, it is worth mentioning that $\mathrm{M}$. Bowley has calculated that the national average at this time was, at 0.8 per cent, even lower: Bowley, Housing, I5.

33 BH, 'CM' (24 March I927).

34 Ibid. (April (?) I943).

35 BH, 'Buxton's Budget' (Io March I932).

36 Ibid.

$37 \mathrm{BH}$, 'The Housing Question' (I6 April I9I9). 
looked towards as providers of housing. Opponents of extensive council housing in Buxton cited traditional economic principles over philanthropic and 'socialist' attitudes in support of these beliefs. It was noted in hindsight, for example, that houses were viewed unfavourably if they failed to recoup their building cost through rent. ${ }^{38}$ Intervention in the housing market through a state subsidy was seen not as a viable social service, but as retarding traditional building, with Buckley proposing that the council stop house building altogether in early I92 I to see if private enterprise would naturally take over, a common suggestion at this time. ${ }^{39}$ When the housing subsidy was cut in I92I under the 'Geddes Axe' it is unsurprising then that the loss of powers was not greatly mourned by the council. Councillor Swain admitted 'Why should we worry?' and suggested letting the private builders get on with the task..$^{\circ}$

It was in the attempted implementation of the Victoria Park Scheme in I935, a sharing of civic responsibility between state, local authority and building firms, that the council truly demonstrated its ideological commitment to private enterprise. Victoria Park, cleared land situated in the working-class district of Fairfield, seemingly offered the perfect location for a working-class residential area. The money for the land was to be borrowed from the ministry of health, and then the building would be undertaken by private firms with some guidance from the local authority. ${ }^{\mathrm{I}}$ Such was the faith in this new scheme that it attracted the support of even the more reforming members of the council (such as Bagshaw, Brindley and Bounds), and the housing committee, now supposedly unneeded, was disbanded in late $1935 .{ }^{42}$ The scheme was expected to cater for all of Buxton's housing needs, whilst absolving the local authority from primary responsibility.

It was clear by the middle of 1937 , however, that this scheme was not going to come to fruition, due to cost, the conditions of the economy, and a difficulty in organisation. Private enterprise was now finally seen as not able to 'meet the requirements' that the council had placed upon it. ${ }^{43}$ Whilst it had taken eighteen years, there was a realisation that the council's notions of civic responsibility would have to change. Unsurprisingly, the Herald also recognised that policies required adaptation. The need for working-class housing now became front-page news as the number of applications for houses grew to four hundred, the number of people living in overcrowded dwellings was revealed to be 792, and the Buxton Ratepayers' Association declared, 'Buxton in this matter cannot sit still.' ${ }^{4}$ The Herald urged progress using any means possible, ${ }^{45}$ whilst Councillor Goodwin, again chairman of the housing committee, made his intent clear: 'The duty of the housing committee is plain and clear - to go forward and build. ${ }^{46}$ The pressure to act mounted on all sides; the kind of apathy shown to previous housing schemes subsided as the press, and pressure

${ }^{8}$ DRO, 'Post-War Development Committee', DI323/2/33/I (26 January I939).

$39 \mathrm{BH}$, 'CM' (9 March I92I).

40 Ibid. (2 November I92I).

4I BH, 'Victoria Park Housing Scheme' (I2 March I936).

42 DRO, 'HATPCM' (November I935).

$43 \mathrm{BH}$, '700 to 900 on the Waiting List' (II March I937).

44 BH, 'Buxton Ratepayers' Association Annual Meeting' (4 April 1938).

$45 B H$, 'Council Housing Policy Attacked' (I3 January I938).

$4^{6} \mathrm{BH}$, 'CM' (I3 January I938). 
groups using the press as a mediator, urged the council onwards. A scheme for sixtytwo houses in Fairfield under the Housing Act of 1935 was pushed through relatively quickly, when compared with earlier schemes, and plans for more houses in the Heath Grove area were in the preliminary stages. Unfortunately, the outbreak of war interrupted this much more progressive programme.

Whilst it is possible at first glance to agree with Bowley's hypothesis that the 'inertia and inefficiency' 47 of local authorities impeded council house building, closer examination, in this case, reveals a complex local culture of perceived responsibility. The 'civic pride' in abolishing slums that Shapely has noted as instrumental in the civic culture and policies of housing in Manchester can be applied equally to Buxton's attempts to safeguard its reputation as a spa town. ${ }^{48}$ Yet when the council had realised its ideologies to be incompatible with the situation at hand, its notions of responsibility did seem to change.

\section{Local-central relations and the nature of state policy}

The important decision to build however was only one part of a long process; in order for a housing scheme to be implemented, it had to be sanctioned first by the ministry of health. ${ }^{49}$ Therefore, if one identifies civic responsibility as a key defining factor, notions of state responsibility must also be examined; the view that the state either had to or should intervene in public housing is too simplistic. Central policy on housing varied immensely throughout the interwar period, changing on average every two and a half years. ${ }^{50}$ Undoubtedly this lack of a cohesive and continuous policy affected the decision-making process of local authorities; stability was essential to an authority that was planning a substantial housing scheme..$^{5 \mathrm{I}}$ Local policy was, therefore, an interpretation and reaction to national policy, based on localised views of circumstances. ${ }^{22}$

The Housing, Town Planning \&c Act I9r9 ('Addison Act') was the first and most generous piece of housing legislation to be passed in this period, since it limited the financial liability of all local authorities to one penny in the pound on the rates. ${ }^{53}$ The authorities in Buxton failed to build any houses under this measure, a fact later rued by the chairman of the housing committee. ${ }^{54}$ This was not due to unwillingness on the part of the Buxton council; the ministry of health would not sanction any of Buxton's proposed schemes, ranging from plans for three houses to more substantial schemes of fifty houses. ${ }^{55}$ It is unsurprising then that it was during the period of the Addison Act that relations between the Buxton council and the government were most strained.

47 Bowley, Housing, 33 .

$4^{8}$ Shapely, Politics of Housing, IоI.

49 Merrett, State Housing, 36.

5o F. Berry, Housing: The Great British Failure (London, I974), 44.

5I Bowley, Housing, ro9.

52 Shapely, Politics of Housing, I8.

53 Daunton, 'Introduction', Councillors and Tenants, 33.

$54 \mathrm{BH}$, 'Rotary Club Meeting' (26 May 1932).

55 DRO, 'HATPCM' (I5 September I92I). 
It is easy to understand the government's rejection of Buxton's proposed schemes; Buxton's tenders for a block of four non-parlour houses submitted to the ministry in February I92I equated to a cost of $£_{\text {II } 20}$ per house. ${ }^{56}$ When compared with the average tender price accepted at this date of seven hundred pounds, which was still much higher than the I9I4 level of $£_{235}$ due to building costs standing at I98 per cent greater than the pre-war level, the housing commissioner's contention that 'the tenders .... are very much in excess of the prices he was prepared to accept' is reasonable. ${ }^{57}$ Due to the nature of the open-ended subsidy, the government was extremely worried about the possible extravagance of local authorities unnecessarily pushing up costs.

Some possible explanations were offered by Buxtonian contemporaries as to why building costs were so high locally. It was mainly believed that it was compulsory to use stone in building, since 'bricks would not do in this neighbourhood, owing to the action of the air'. ${ }^{8}$ When Buxton did eventually use bricks, it was then argued that Buxton's 'isolated position' from the brickfields made transport costs restrictive. ${ }^{59}$ The cost of preparing foundations, roads and sewers was also high due to the town 'being on the rock' - alluding to the limestone composition of the area. ${ }^{60}$ Whilst these factors may have been valid, private correspondence between the ministry and the Buxton council reveals more telling factors: the impact the civic perception of Buxton's councillors had on house design and, consequently, housing cost. Following the request of the ministry architect that attention be given to economy, the housing committee tersely replied: 'The class of house indicated by the commissioner is, in the opinion of this committee, entirely unsuitable, and will in a few years become slum property. ${ }^{\text {'I }}$

Consequently, the housing committee would not accept any of the commissioner's economy modifications on room size or materials, and so did not receive sanction for the Addison subsidy. ${ }^{62}$ The committee instead proceeded with its own designs on the Cliff Road site of Fairfield, using the Housing of the Working Classes Act of I890, which granted a lump subsidy of $£_{2} 60$ per house but did not entail government supervision in design (see Figures I and 2). The results were viewed disdainfully by locals and in the press on aesthetic grounds, with criticism ranging from 'scathing to deadly' and, at an excessive cost of $£_{\mathrm{II} 78}$ per house, the council was further secured in its preference for private enterprise. ${ }^{63}$ Whilst it is debatable whether the council wished to have the role of a local housing provider, the houses that were built had to be of a high standard in order to maintain Buxton's image as a spa town. As one post-I945 planner stated: 'rows of box-like industrial dwellings do not harmonise with the distinctive general architecture of the town' ${ }^{64}$ This stipulation in local policy drove up costs and provided a distinct barrier in central-local relations.

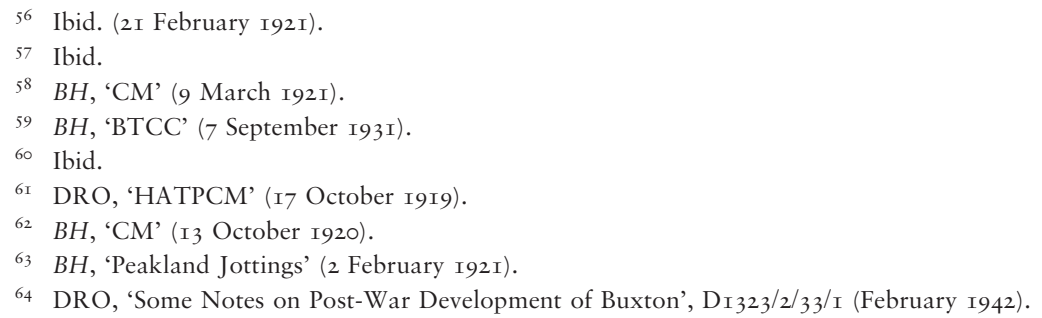




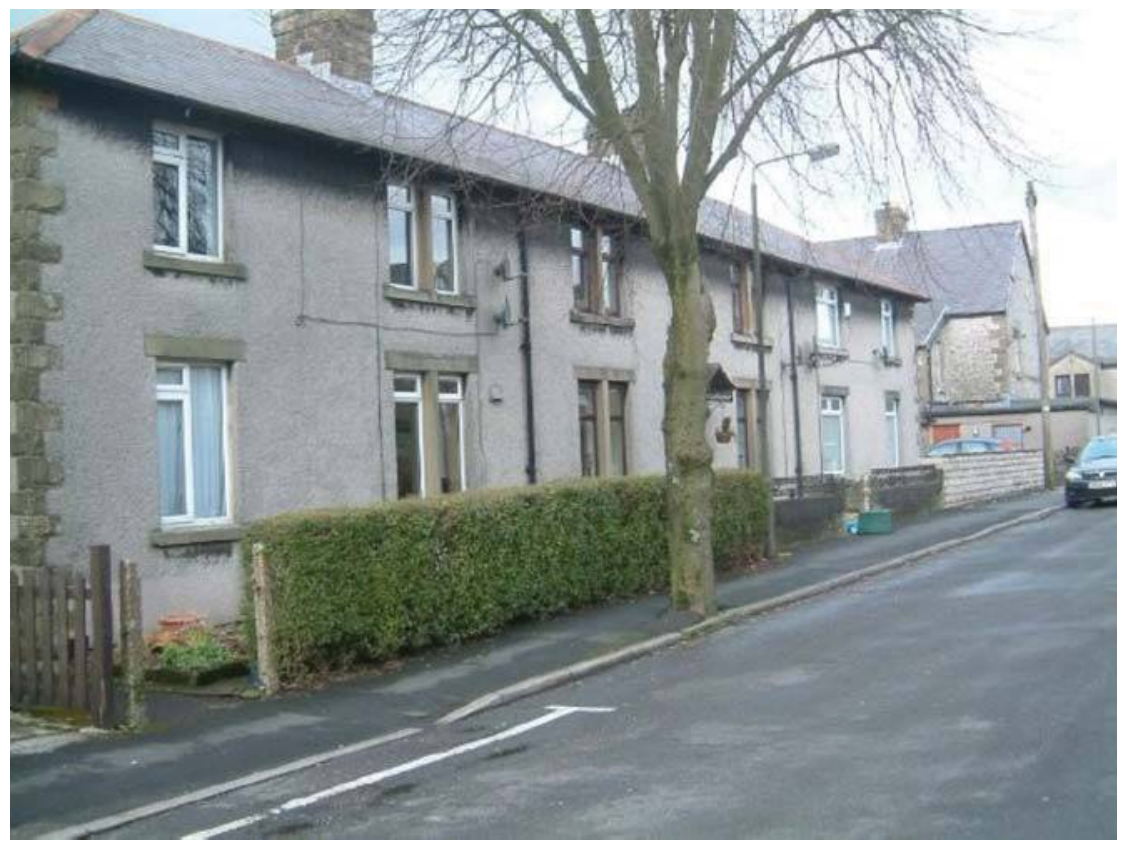

FIGURE 1 Cliff Road (Fairfield) Houses, built 1921.

Photo: author

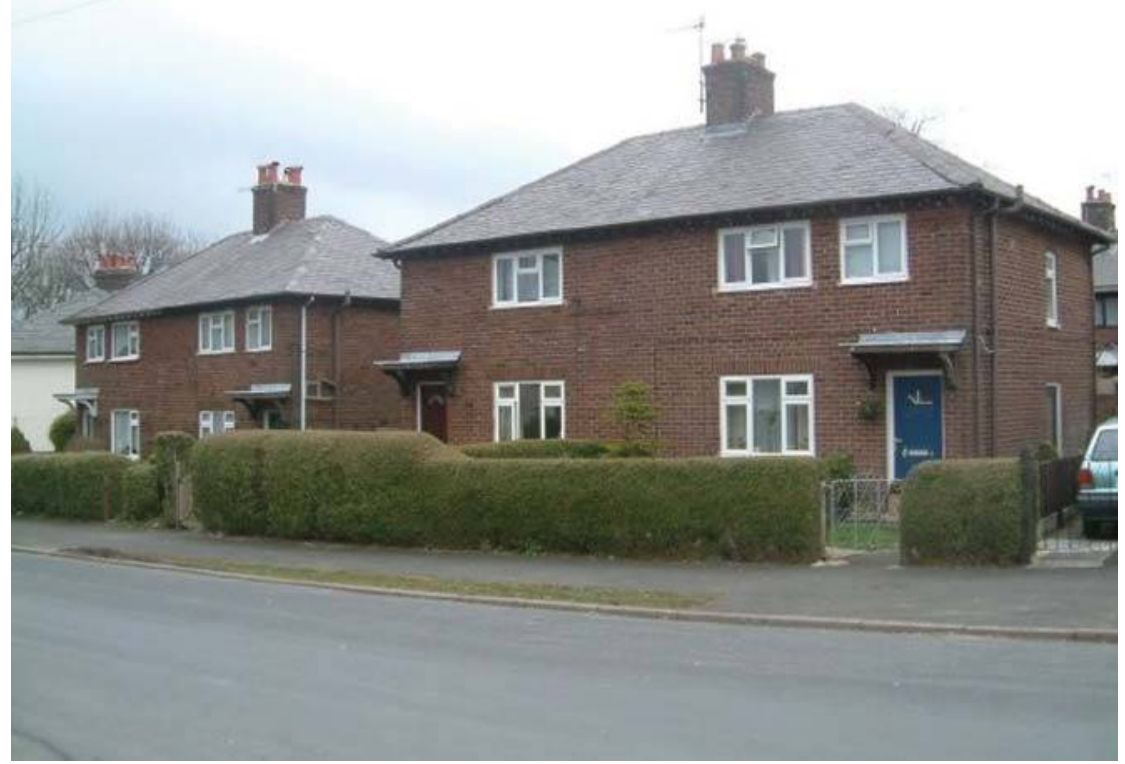

FIGURE 2 Sherwood Road (Heath Grove Site), built 1926. After the erection of the Cliff Road houses, which were uniquely designed but criticised on an aesthetic and cost basis, the Buxton council resolved to use the now widely familiar designs as provided by the ministry of health for the rest of the town's schemes.

Photo: author 
Still, the national conditions that were forcing building costs to be so drastically high in the early I920s were beginning to abate; the prices of most building materials and wages did not rise in I920, and by I92I were either static or falling. ${ }^{65}$ After reaching a peak average of $£_{930}$ per house in August I920, costs steadily fell to $£_{665}$ in July I92I. ${ }^{66}$ It is not unreasonable to suggest that the price of building in Buxton could have followed this trend to an extent where the tenders were at a low enough level to be palatable for the ministry of health. Yet, though costs were falling, the government decided at this point to discontinue the Addison subsidy as part of the so-called 'Geddes Axe', a series of cuts in public expenditure.

This seemingly 'perverse reversal' has garnered much debate in the historiography of council housing. ${ }^{67}$ Swenarton's persuasive argument in favour of viewing the passing of the Addison Act as an 'insurance against revolution', pointing towards the high standard of architecture and design, contends that with the collapse of the postwar boom the power of labour was drastically reduced - negating the need for pacification through social reform. ${ }^{68}$ The increasingly vocal Anti-Waste League now had justification for their calls to cut public expenditure. ${ }^{69} \mathrm{M}$. J. Daunton, however, has argued that more emphasis should perhaps be placed upon the government's desire to deflate and return to the Gold Standard - the orthodox economic theory of the period. ${ }^{70}$

Whilst it is difficult to arrive at a conclusive explanation for why the government cancelled the subsidy at this time, the message that the action conveyed was clear: local authorities had been absolved of their responsibility. In 1922 the new minister of health expressed the hope 'that future State intervention will not be required, and that the building industry will return to its pre-war economic basis' ${ }^{7 \mathrm{I}}$ That the pre-I9I4 'welfare state' measures of social insurance, old-age pensions and free elementary education were not cut back by the Geddes Axe displays that the state's interpretation of their responsibility did not extend so readily to housing. ${ }^{72}$ This was greeted not with surprise, but with a mixture of praise and regret at the local level. The Herald stated, 'It is clear then that the housing problem will not be solved by public bodies meddling in building matters' ${ }^{73}$ whilst Councillor Swain lamented that 'the Government had not carried out their agreement'. ${ }^{74}$

Local-central relations had not commenced in a constructive manner. The Buxton authorities viewed the government as unnecessarily blocking schemes, whilst the government could not see past the admittedly high costs in Buxton. Relations were to improve however, as consequently did the construction rate in Buxton. Whilst the Housing \&c Act 1923 ('Chamberlain Act') attempted to restore private enterprise

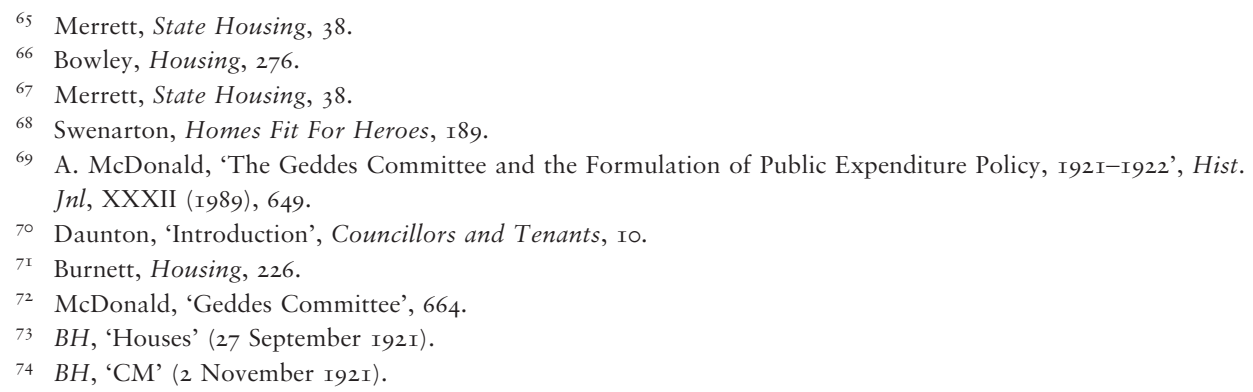


as the suppliers of working-class housing, and in line with prevailing Conservative ideologies, it did also offer a subsidy to local authorities - though they had to prove that they were fulfilling a role private enterprise could not. ${ }^{75}$ After the crescendo of costs the treasury had experienced with the Addison subsidy, Chamberlain fixed the subsidy at the rate of six pounds per annum per house for twenty years. This left state intervention at a relatively low and secure level, since expenditure by local authorities did not need to be overly supervised. ${ }^{76}$ The Housing (Financial Provisions) Act 1924 ('Wheatley Act'), passed under Labour, also followed this guideline, though with a much higher subsidy of nine pounds per annum per house for forty years. Wheatley also reversed the Chamberlain policy of local authorities having to prove that they were providing a service private enterprise could not, re-establishing local authorities as the provider of social housing. ${ }^{77}$

The Buxton housing committee now had less trouble in achieving authorisation for schemes. As the housing commissioner stated in I925: 'it is noted that the tender proposed to be accepted is high, and that the loan is now sanctioned on the assumption that the council has satisfied themselves there is no prospect of obtaining lower prices' ${ }^{78}$ Costs indeed still remained relatively high. In 1925 tenders for non-parlour houses in Buxton stood at $£ 680$, compared to the national average of $£_{5} \mathrm{IO}$. Whilst the liability of the treasury was now secure, the councillors of Buxton were left with an unenviable choice; either subsidise the high cost out of the rates, or charge higher and more economic rents. Whilst this subsidy policy was more welcome than none at all, and the difference in tenders between Buxton and the national average had actually fallen to twenty-four pounds in I933, the lack of an equalising nature in the legislation meant the Buxton authorities had more of a burden than an area with low building costs for much of the I920s. ${ }^{79}$

Yet it was arguably the unstable and changing nature of the subsidies that hindered progress the most; as the central party in power changed, so did notions of state responsibility and, consequently, the subsidy granted. The Conservative party clearly viewed state intervention in housing as a temporary measure to remove shortages so that controls over the housing market could be ended. ${ }^{8 \circ}$ Macintyre has taken this even further, stating that the Conservatives' commitment to reform was, at best, 'shallow'; Conservative measures represented a pragmatic and populist response to the growing power of the Labour Party and the electorate. ${ }^{8 \mathrm{I}}$ It was the Labour Party that unsurprisingly introduced the more progressive and generous subsidies, such as the Wheatley Act, though they lacked the political and economic stability to implement them. ${ }^{82}$ It was mostly therefore a Conservative government that administered

75 C. Macintyre, 'Policy Reform and the Politics of Housing in the British Conservative Party I924-I929', Aust. Jnl Pol. Hist., 45/3 (1999), 4I9.

$7^{6}$ J. Dale, 'Class Struggle, Social Policy and State Structure: Central-Local Relations and Housing Policy, I919-I939', in J. Melling (ed.), Housing, Social Policy and the State (London, I980), 2 I2.

77 Bowley, Housing, 4I.

78 The National Archives (hereafter TNA), HLG/49/I38 (April I925), 'Fairfield Site I924-I935'.

79 Costs in this paragraph calculated from Bowley, Housing, 278, and DRO, 'HATPCM'.

8० Daunton, 'Introduction', Councillors and Tenants, I5.

8I Macintyre, 'Policy Reform', 423.

82 Burnett, Housing, 249. 
the subsidies, a government that did not wish to see subsidies continued beyond the minimum amount of time. ${ }^{83}$

Ideological differences between parties were exposed clearly in the administration and manipulation of housing legislation. The Conservative Chamberlain Act, which was initially only for a period of two years, was extended by Labour for fifteen years in I924, only to be cancelled in 1929 by a Conservative government. The actual amount the subsidy granted was reduced by the Conservatives in 1927 to two-thirds of its value, whilst the Wheatley subsidy was lowered from nine pounds to $£_{7}$ Ios, in a measure of economic retrenchment. Bowley has noted the significant drop in the investment of local authorities following these reductions; whilst Conservatives thought that falling building costs would offset the cutback, housing committees felt unease at starting new schemes in an unstable economic environment. ${ }^{8}$ This was particularly noticeable in Buxton; no new schemes were commenced from I927 to I930, until costs had fallen significantly. ${ }^{85} \mathrm{~J}$. Dale has viewed such central actions of reduction in subsidy amount and timescale as a vital tool that central authorities could utilise to curb building, and therefore costs, without creating confrontation with local authorities - a seemingly successful tactic in the case of Buxton. ${ }^{86}$

Housing policy under the Chamberlain and Wheatley Acts was clearly erratic; local authorities faced continually changing circumstances. When the Wheatley subsidy was cancelled in 1933, after the recommendations of a committee on local expenditure in $1932,{ }^{87}$ there was no sign of protest from Buxton councillors. With the passing of the Housing Act 1930 ('Greenwood Act') policy was to turn to a sanitary policy of slum clearance - though it was effectively postponed until I933 due to economic instability. ${ }^{88}$ This legislation was then supplemented with the Housing Act 1935, which offered a subsidy of five pounds per annum for twenty years for each dwelling erected to overcome overcrowding. Yet from the cancellation of the Wheatley subsidy until the proposed Dale Lane scheme in I938, no plans from Buxton were submitted, nor were any houses constructed.

The government certainly did not push the Buxton authorities towards a programme of slum clearance, since only towns of twenty thousand or more were required to prepare a specific plan for an attack on the slums. Though the health committee only condemned I 35 houses as unfit in the whole of the $1930 \mathrm{Os},{ }^{89}$ the permissive nature of state legislation meant that local authorities could evade their duties no matter how small; failure at the local level should also be viewed partly as a failure of the ministry of health. ${ }^{\circ}$ As long as the government was unwilling to force its hand, it seems the Buxton council was quite content to wait for private enterprise. As far as local councillors were concerned, the state had, following the cancelling of the Wheatley subsidy in I933, again rejected its responsibility for housing, after a

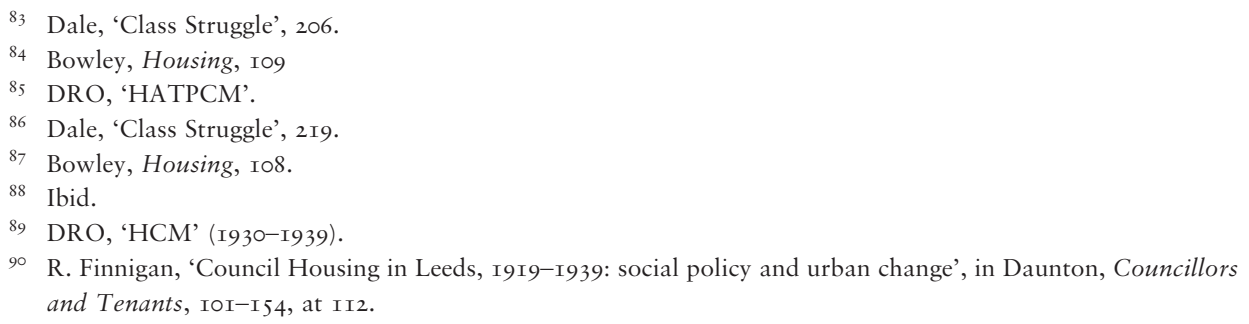


gradual erosion of subsidies in generosity and timescale. To a certain extent this authorised and informed the views of Buxton councillors on the nature of civic responsibility; as Ryder states: '[not] any one local authority operated in a vacuum outside the changeable atmosphere of the central government policy'. ${ }^{\mathrm{I}}$ The new slum clearance policy was seemingly not viewed as a crisis; it was only when the Victoria Park Scheme failed that the housing situation reached this point, and the housing committee was re-formed with a more progressive outlook.

\section{The council as landlord}

Though the council may not have wanted to build, their role following construction is still worth examination, since the policies followed by the council affected the lives of the new tenants, and their use of urban social space..$^{22}$ The variety of choices to be made by the council were both unfamiliar and problematic, none more so than the setting of rents and the policy of tenant selection. Decisions made in this respect form the core of the 'housing problem' of the interwar period; namely, who should benefit from the new and novel public intervention in the field of housing. Yet the extent of housing management goes beyond this; the movement of people from varying communities into newly planned areas marked a watershed in local roles of intervention. ${ }^{93}$ Robert Finnigan has stressed the necessity of questioning these estates, and the extent to which new communities were created as opposed to 'mere aggregations of dwellings'. ${ }^{94}$ Local authorities had a 'wide measure of autonomy' from the ministry of health in this respect. ${ }^{95}$ It is unsurprising then that localised views of civic responsibility again shaped the policies that the council implemented.

The setting of rent levels was a balancing act, with the weight of the variables determined by local opinion. In order for rents to be low, the burden upon the rates had to be higher so as to subsidise the cost of building. For much of the interwar period in Buxton there was a tendency to view this as a negative measure. As the Herald stated: 'all subsidies are bad. Every article, whether large or small, a pin or a house, should pay for its manufacture. ${ }^{96}$ The housing committee, in the main, agreed with this assessment, stating that 'it is the duty of the Council to see that the rents approximate, even if they do not actually reach, the economic level'. ${ }^{97}$ The high cost of building meant either a considerable percentage had to be paid out of the rates, or rents had to be substantially higher. The housing committee chose to utilise the Chamberlain subsidy until it was discontinued, as opposed to the more generous

9r Ryder, 'Council House Building in County Durham', 90.

92 C. G. Pooley, 'Patterns on the Ground: Urban Form, Residential Structure and the Social Construction of Space', in M. J. Daunton (ed.), The Cambridge Urban History of Britain, vol. 3 (I840-I950) (Cambridge, 2000), 464 .

93 Burnett, Housing, 234.

94 Finnigan, 'Council Housing in Leeds', I34. M. Clapson has discussed how the social life on such estates was, in the majority, a favourable experience for those who moved there: M. Clapson, 'Working-Class Women's Experiences of Moving to New Housing Estates in England since 1919', 2oth Cent. Brit. Hist., Io/3 (1999).

95 J. B. Cullingworth, Housing and Local Government (London, I966), 63.

96 BH, 'BTCC' (9 August 1923).

97 Ibid. (I2 June I924). 
Wheatley subsidy, since it gave full control over the setting of rents. The level decided upon for the parlour houses built between 1923 and 1926 therefore was I4s od per week, exclusive of rates. ${ }^{98}$

That this seems very high, compared to the national average rent of council houses of $7 \mathrm{~s} 9 \mathrm{~d}$ in 1926 , is perhaps irrelevant. ${ }^{99}$ What is more revealing is the difficulty the inhabitants of Buxton's council houses had in paying these rents. By I932, I5 per cent were in arrears, a figure not surprising given the level of unemployment at this time. ${ }^{100}$ Individual cases reveal a far more substantial problem. For example, one household accrued an incredible $£_{43}$ of arrears in three years - though it is necessary to note that one of the two adult occupants died part way through the tenancy. ${ }^{\text {IOI }}$ Another case displays a more pressing issue. In five years of tenancy, one tenant had let arrears build up to the sum of $£_{\mathrm{I}} 8$. When he had taken up the tenancy, with his wife and four children, he was earning a wage of $£_{2}$ Ios a week. He was, therefore, paying almost 33 per cent of his wage in rent. ${ }^{\text {IO2 }}$ As the housing committee recognised, the rent levels were far out of the tenant's reach, and were more suited to a wage of $£_{4}$ or $£_{5}$ a week. ${ }^{\text {103 }}$

It is here that a substantial flaw and contradiction in the council's rent levels and tenant selection is apparent. It has been recognised in the historiography of council housing that many local authorities operated a pragmatic approach to tenant selection, choosing those more 'desirable' and able to pay. ${ }^{\text {I04 }}$ This led to a situation where council houses were effectively limited to 'the better-off families, the small clerks, the artisans, the better-off semi-skilled workers with small families and fairly safe jobs' ${ }^{\text {I05 }}$ Yet the Buxton council did not display any such 'vetting' of tenants, and openly prided itself upon guaranteeing that those most in need got the houses first - regardless of ability to pay. ${ }^{106}$ The tenant selection process was delegated to the philanthropically minded Women's Advisory Committee, who strived to alleviate the 'worst and distressing cases'. ${ }^{107}$ The result of this, however, was frequent rent arrears and subsequently a strict eviction policy following three weeks of non-payment. ${ }^{\text {I08 }}$

The council's policy towards rent levels did become more progressive - though this correlated with falling cost levels as well, as Table 2 shows. The key changing point in policy came in I930, when the council was forced to use the Wheatley Act, due to no other subsidies being available. This confined rents to a maximum level. Eventually the council even went further than this, reducing the rents of the Chamberlain houses from I4s od to I2s $6 \mathrm{~d}$, Ios $6 \mathrm{~d}$ to $9 \mathrm{~s} 6 \mathrm{~d}$, and Ios od to $9 \mathrm{~s} 6 \mathrm{~d}$, and

\footnotetext{
98 Ibid. (1923-1926).

99 Merrett, Housing, 49.

100 Calculated from BH, 'BTCC' (I2 May I932).

ror $B H$, 'Small House Problem in Buxton' (I7 September I93I).

${ }^{102}$ Ibid.

ro3 Ibid.

${ }^{104}$ Daunton, Councillors and Tenants, 24.

ro5 Bowley, Housing, I29.

${ }^{106} \mathrm{BH}$, 'BTCC' (I2 January I925).

${ }^{107} \mathrm{BH}$, 'CM' (30 October I924).

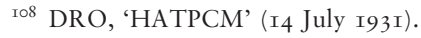


TABLE 2

BUILDING, COSTS, HOUSE TYPE AND RENTS

\begin{tabular}{|c|c|c|c|c|}
\hline Act used & Year* & Type & Cost & Initial rent \\
\hline 1890 Act & 1921 & Parlour & $£ 1178.00$ & $12 s 6 d$ \\
\hline Chamberlain & 1923 & Non-parlour & $£ 505.00$ & $10 \mathrm{~s} \mathrm{0d}$ \\
\hline Chamberlain & 1923 & Parlour & $£ 680.00$ & $14 \mathrm{~s} 0 \mathrm{~d}$ \\
\hline Chamberlain & 1924 & Parlour & $£ 680.00$ & $14 \mathrm{~s} 0 \mathrm{~d}$ \\
\hline Chamberlain & 1926 & Parlour & $£ 681.00$ & $14 \mathrm{~s} 0 \mathrm{~d}$ \\
\hline Chamberlain & 1926 & Non-parlour & $£ 564.00$ & $10 s 6 d$ \\
\hline Chamberlain & 1926 & Non-parlour & $£ 526.00$ & $10 \mathrm{~s} \mathrm{0d}$ \\
\hline Wheatley & 1930 & Non-parlour & $£ 450.00$ & $7 \mathrm{~s} 8 \mathrm{~d}$ \\
\hline Wheatley & 1931 & Non-parlour & $£ 432.00$ & $7 s 6 d$ \\
\hline Wheatley & 1933 & Non-parlour & $£ 386.00$ & $6 s 6 d$ \\
\hline
\end{tabular}

*Year building commenced

SOURCE: DRO, 'HATPCM' (1918-1945).

the Wheatley houses from $7 \mathrm{~s} 8 \mathrm{~d}$ to $6 \mathrm{~s} 6 \mathrm{~d}$ in $1933 .{ }^{109}$ This placed an extra burden of $£_{\mathrm{I} 52}$ per annum on the rates. ${ }^{\text {IO }}$ Rent reductions, whilst an improvement, were not substantial. It is unsurprising then that the tenants of the first Chamberlain houses greeted the news with indignation and 'disgust', since lowering rents was an admission that they were too high, but the amount was so small that it did not make a tangible difference. ${ }^{\text {III }}$ Predictably perhaps, and to the dismay of councillors, a high amount of subletting continued, with the result that the overcrowding rate in municipal houses in 1936 was twice as high as in standard working-class dwellings. ${ }^{\text {II2 }}$

Management of council houses also involved much more than rent policy, such as the fostering and assimilation of communities. This presented less of a problem for the housing schemes located in the Fairfield area of Buxton since these schemes were integrated into what was already recognised as a 'working-class district'. ${ }^{\text {II3 }}$ Fairfield was well equipped with a post office, newsagents, fishmongers, dairyman and confectioner, and was within a short distance of the shops and recreational activities of

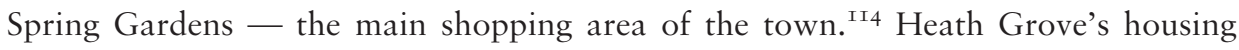
estate presented a greater problem in this respect, being some distance from 'the town's main attractions'. ${ }^{\mathrm{II}}$ With 77 per cent of Buxton's council houses located on this new and peripheral estate, the formation of a community was essential; it was in

\footnotetext{
${ }^{109}$ Ibid. (I4 March I933).

i ${ }^{\circ}$ Ibid.

${ }^{\text {III }}$ BH, 'Letters Page' (9 March I933).

${ }^{\text {II2 }} \mathrm{BH}$, 'Overcrowding in Buxton' (4 June I936).

II3 TNA, HLG/49/I38 (20 January I925), 'Fairfield Site I924-I935'.

${ }^{I I} 4$ D. G. Owen, The Day Before Yesterday: A Fairfield life (Ashton, 2002).

${ }^{115}$ M. Langham, Buxton: A People's History (Lancaster, 200I), 2 I4.
} 
reality only on Heath Grove that 'families had to build up a new neighbourhood and community life from the beginning' ${ }^{\text {II6 }}$

Through the employment of an architect, and substantial deliberation, the estate took on a well-planned exterior. The maintenance of the properties on the estate was of clear importance to the council, and the housing committee employed a housing manager, a decision only one-fifth of local authorities took in this period. ${ }^{117}$ The housing committee and housing manager were willing to provide the funds to paint fences, erect sheds, and make other improvements on the estate. ${ }^{\text {II } 8}$ Furthermore, in cooperation with Buxton Gardeners' Association, yearly cash prizes of $£_{\mathrm{I}}$ Ios (approximately two weeks' rent and rates) were given to the best presented garden, with amounts also given to second and third place. ${ }^{\text {II9 }}$ This arrangement was mutually beneficial; tenants had a more attractive property, whilst the council could maintain the image of Buxton as a pleasant spa town. The council also actively secured and maintained a substantial piece of land, though this did change location in the mid I930s, as a recreational ground for local children. This site remains a focal point for the youth of Buxton today. ${ }^{\mathrm{I} 2}$ This small but important measure displays that feelings of civic responsibility did extend beyond the maintenance of Buxton's image as a leisure destination; only the most cynical observer would suggest that the welfare of its new tenants was completely superficial.

Though these small measures did help formulate a sense of community on Heath Grove, it was still substantially lacking in the shops and amenities that were numerous in Fairfield and other parts of the town. Perhaps even more important than this was Heath Grove's isolation from the workplace. This fact was certainly recognised by some councillors: Councillor Sawdon appreciated that railwaymen could be called up for work with ten minutes notice, and so living on Heath Grove was not an option. ${ }^{\text {I2I }}$ Others were not as sympathetic: Councillor Macdonald protested that he had to travel across Buxton and then fifty more miles to work. ${ }^{\text {I22 }}$ Travel was particularly problematic for those who worked at the Grin Works lime quarry and other places in the area of Burbage. As Councillor Wilde stated: 'They did not want to come to Heath Grove when they had finished work.' ${ }^{\text {I23 }}$

That the council encountered problems with tenant selection, location and amenities is to be expected. As Jevons and Madge conceded: 'it is perhaps inevitable that any authority which embarks for the first time on an ambitious programme of housing will make serious mistakes'. ${ }^{\text {I24 }}$ Buxton council's mistakes were perhaps not so much in the housing it built, but in its inability to provide the quantity to overcome the growing deficit.

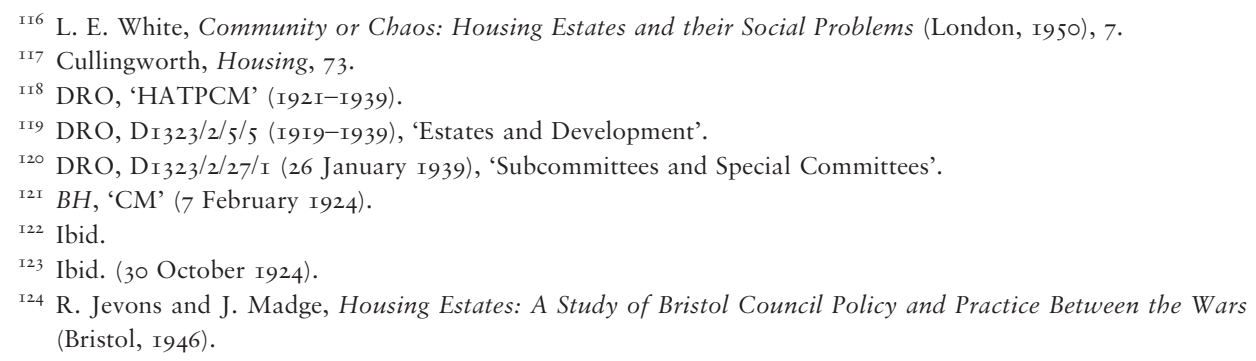




\section{Conclusion}

In 1938 alone the number of new housing applications was $399,{ }^{\text {I25 }}$ whilst the existing waiting list was already 'anything from 700 to 900 ' in $1937 .{ }^{126}$ Whilst the council steadfastly denied that this quantity equated to the housing need in the area, indeed their estimate was a more conservative two hundred houses, there was still an admission that not enough houses had been built to relieve a problem that was growing into a crisis. ${ }^{127}$ This figure of two hundred was only seventy or so less than the council had built in the whole of the interwar period, an indicator of how far behind the housing schemes had fallen. The I 920 evaluation of housing need had been estimated at fifty houses, and, by this barometer, the council had met and far surpassed the supposed need. Yet the need for houses constantly grew, and at a much faster rate than the council could meet.

Yet if the pace of the early I930s had been maintained, when I40 houses were built in three years, it is not unrealistic to suggest that the housing needed in I939 could have been a much less significant amount. Whilst the cancelling of the Wheatley subsidy in I933 actually marked the end of municipal house building in Buxton in this period, it is too simplistic to place all of the blame upon the central state and the limitations of its policies. Instead, it is necessary to reaffirm the significant impact that the failure of the Victoria Park scheme had on the housing problem in Buxton. This scheme would have provided two hundred working-class dwellings, with space for future development. The policy followed by the council, essentially preparing plots of land abutting onto roads, which were then to be sold to private builders under strict letting conditions, failed. ${ }^{\mathrm{I} 28}$ Quite simply, because of the conditions suggested by the council, the income return was not attractive enough to entice private builders to build down to the rent level needed, essentially the issue at the crux of discussions of state intervention before even I9I4. ${ }^{\text {I29 }}$ Whilst the preparation of the land had taken longer than envisaged, the rising building prices in $1936-7$ exacerbated this situation, and essentially crippled the potential of the scheme. ${ }^{130}$

Nonetheless, other subsidies for municipal house building were open to the Buxton council following I933. That they did not take these subsidies represents the key issue of Buxton's strategy in the interwar period; once the government had seemingly reversed the policy of underlying responsibility for general housing needs, local notions of responsibility followed suit. That the council placed all of its hopes on collaboration with private enterprise on the Victoria Park land reveals its commitment to existing notions of civic responsibility in the field of house building. The perceived civic identity of Buxton was its reputation as a quaint spa and leisure town, defined in opposition to the notion of the big city and its slums. The very idea that such a town could experience a working-class housing crisis was mostly ignored in the town until the late I930s, when the problem broke away from the editorial and comments pages of the Herald, and became consistently front-page news.

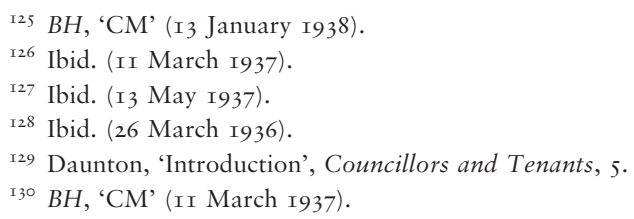


Clinging to the ill-judged scheme of Victoria Park, and instead concentrating on tourism and leisure functions, stagnated any other possible municipal house building for most of the I930s. By the time the council realised that private enterprise could not function in Buxton to the extent required, it was too late: the schemes prepared were interrupted by the Second World War. Postwar opinion from the Herald and the council displayed an admission that the policies and notions of responsibility, which had essentially hampered municipal house building, had to change if Buxton was to overcome the housing crisis. Clear regret was shown for the 'former slackness' identified by the progressive-minded Councillor Bagshaw, who had now risen to chairman of the postwar housing committee. ${ }^{\text {I3I }}$ The Herald lamented: 'Would that we could put the clock back fifteen years and make the housing estates twice as big as they are. Now it is too late. ' ${ }^{2} 2$ The postwar housing committee now realised that former policies were 'short-sighted and wrong' and that the responsibility for housing workers from outlying industries was the duty of the local authorities and not the industries in question. ${ }^{\mathrm{I} 33}$ Such regret, which was essentially based on the astute realisation that past principles had been misguided, must not be taken out of context with the benefit of hindsight. It would be naïve to suggest that the council could, or should, have adapted to their new role as house providers with enthusiasm and success straight away. The existing civic culture and notion of civic responsibility were formidable barriers to overcome in this respect - barriers made higher by the changeable and uncertain nature of state policy and state responsibility.

\section{Notes on contributor}

T. J. Hulme, Centre for Urban History, University of Leicester, Mare Fitch House, 3-5 Salisbury Road, Leicester LEI 7QR, UK. Email: th7I@le.ac.uk

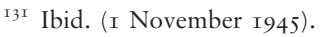

${ }^{132} \mathrm{BH}$, 'Buxton's Houses' (24 January I946).

${ }^{133} \mathrm{BH}$, 'Post-War Planning' (I7 June I943).
} 